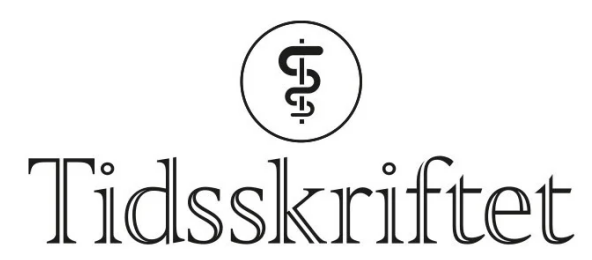

DEN NORSKE LEGEFORENING

\title{
Indias pandemier
}

FRA REDAKTØREN

\section{KARI TVEITO}

kari.tveito@tidsskriftet.no

Kari Tveito er ph.d., lege og medisinsk redaktør i Tidsskriftet.

\section{Mens nattelivet åpner i Europa og USA, lyser flammene fra likbål opp himmelen over Indias millionbyer.}

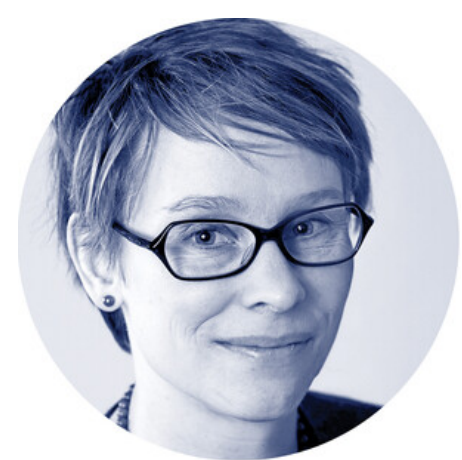

Foto: Einar Nilsen

En gryende optimisme preget landet. Flokkimmunitet var oppnådd flere steder, og pandemien var på hell. Trodde man. Statsminister Narendra Modi samlet svære menneskemengder under valgkampen i mars og april og tillot millioner av indere å valfarte til byen Haridwar ved elva Ganges under den religiøse festivalen Kumbh Mela.

Men det brygget opp til det som gjerne kalles en perfekt storm (1). Koronaviruset fikk bortimot fritt spillerom i en befolkning på nesten 1, 4 milliarder mennesker, hvorav under 2 \% var fullvaksinert. Den nyoppståtte indiske virusmutasjonen med betegnelsen B.1.617 bidro muligens også til en eksplosiv smitteøkning. I slutten av april sto India for nesten halvparten av alle rapporterte covid-19-tilfeller på verdensbasis, med over 400 ooo registrerte smittede per dag-i tillegg til store mørketall.

Forbundsstaten, som bærer en fjerdedel av den globale tuberkulosebyrden, er blant de landene i verden som investerer minst i helse. Kun drøye $1 \%$ av bruttonasjonalproduktet går til offentlige helsetjenester (므). Tilsvarende tall for Storbritannia og USA er $9 \%$ og $16 \%$. Det er også store forskjeller mellom de 28 delstatene, som alle fører sin egen helsepolitikk. Etter kvalitet på og tilgang til helsetjenester ble India i 2018 rangert som nummer $145 \mathrm{av}$ 195 land, lavere enn Kina, Sri Lanka og Bangladesh (3). Norge var for øvrig nummer 2 på listen, rett bak Island på topp. 
Et helsevesen som i utgangspunktet fungerer marginalt, kollapser under en folkehelsekrise som covid-19-pandemien. Medier over hele verden har formidlet hjerteskjærende historier om koronasyke som dør hjemme, på gaten eller på sykehus fordi de ikke får nødvendig helsehjelp. Det mest prekære - mangelen på medisinsk oksygen - har av høyesterett i Indias mest folkerike delstat, Uttar Pradesh, blitt karakterisert som et folkemord (4).

«Et helsevesen som i utgangspunktet fungerer marginalt, kollapser under en folkehelsekrise som covid-19-pandemien»

Systemet har sviktet, men folket har reist seg. Via Twitter, Facebook og Instagram skaffes oksygenkolber, plasmadonorer og sykehusplasser til fremmede så vel som venner og familiemedlemmer. Måten sikhtempler i tillegg til gratis måltider nå tilbyr oksygeninhalasjoner til fattige på, kan tjene som et bilde på denne indiske jugaad. Ordet, som vanskelig lar seg oversette, men blant annet har fått innpass i det engelske språket, betyr noe sånt som å finne uventede og originale løsninger under vanskelige omstendigheter.

Paradoksalt nok har India, som utryddet polio med verdens største vaksinasjonsprogram, ikke klart å vaksinere mer enn noen få prosent av befolkningen mot covid-19. Myndighetene har derfor sett seg nødt til å stoppe all vaksineeksport. Dette innebærer en global helsetrussel, fordi India er en av verdens største vaksineprodusenter, blant annet av AstraZeneca-vaksinen. Nå uteblir leveringen av vaksiner og vaksinekomponenter til mer enn 70 nasjoner. Lav- og middelinntektsland, som skulle få vaksiner som en del av Covaxprogrammet, rammes spesielt hardt.

Risikoen for komplikasjoner av covid-19 på grunn av overvekt ser ut til å være særlig høy blant yngre voksne (5). Det er en dårlig nyhet for India, der mer enn $65 \%$ er under 35 år og overvekt er et betydelig folkehelseproblem sammen med diabetes (므). Hvor stor betydning fedmeepidemien har under den andre smittebølgen, er usikker, men indiske sykehus melder om flere alvorlige forløp hos unge pasienter enn før og at mange av disse er overvektige (7.).

\section{«Systemet har sviktet, men folket har reist seg»}

I verdens mest forurensede hovedstad, Dehli, var munnbind ofte påkrevd også før koronakrisen. Røyk og eksos fra industrianlegg, jordbruk og trafikk ligger som et teppe over episenteret for covid-19, spesielt i vintermånedene, og utgjør en betydelig helserisiko for innbyggerne. Stort bedre er det ikke i de andre store byene: Luftforurensning krever ett barns liv hvert tredje minutt og er den tredje største dødsårsaken i India ( $\underline{8})$. Denne langsomme pandemien er mindre synlig, men like farlig som katastrofen vi i dag bivåner.

Situasjonen i India er en viktig påminnelse om hvor viktig forebyggende folkehelsearbeid og et velfungerende helsevesen er. Akkurat nå må branner slukkes, og det internasjonale samfunnet har heldigvis trådt til. Vi har en moralsk forpliktelse til å lindre menneskelig lidelse, men innsatsen tjener oss alle. For koronapandemien tar ikke slutt før den er over i alle land. Det haster mer enn noen gang å gjennomføre det globale vaksinasjonsarbeidet. Og så trengs det en dose av den indiske jugaad.

\section{LITTERATUR}

1. Ellis Petersen H. WHO blames 'perfect storm' of factors for India Covid crisis. Guardian 27.4.2021. https://www.theguardian.com/world/2021/apr/27/international-aid-arrives-in-india-to-combat-deadlycovid-crisis Lest 5.5.2021. 
2. World Health Organization. Global Health Expenditure Database.

https://apps.who.int/nha/database Lest 7.5.2021.

3. GBD 2016 Healthcare Access and Quality Collaborators. Measuring performance on the Healthcare Access and Quality Index for 195 countries and territories and selected subnational locations: a systematic analysis from the Global Burden of Disease Study 2016. Lancet 2018; 391: 2236-71. [PubMed] [CrossRef]

4. Halvorsen T. Indisk høyesterett om oksygenmangel og dødsfall:- Et folkemord. Dagbladet 5.5.2021. https://www.dagbladet.no/nyheter/et-folkemord/73726740 Lest 5.5.2021.

5. Gao M, Piernas C, Astbury NM et al. Associations between body-mass index and COVID-19 severity in 6.9 million people in England: a prospective, community-based, cohort study. Lancet Diabetes Endocrinol 2021; 9: S2213-8587(21)ooo89-9. [PubMed][CrossRef]

6. Luhar S, Timæus IM, Jones R et al. Forecasting the prevalence of overweight and obesity in India to 2040. PLoS One 2020; 15: e0229438. [PubMed][CrossRef]

7. Jha DN. Is obesity adding to covid-19 complication risk in the young? Times of India 1.5.2021. https://timesofindia.indiatimes.com/city/delhi/is-obesity-adding-to-covid-19-complication-risk-inyoung/articleshow/82335004.cms Lest 5.5.2021.

8. State of Global Air. https://www.stateofglobalair.org/ Lest 8.5.2021.

Publisert: 10. mai 2021. Tidsskr Nor Legeforen. DOI:10.4045/tidsskr.21.0394

(C) Tidsskrift for Den norske legeforening 2023. Lastet ned fra tidsskriftet.no 26. april 2023. 